\title{
Integrating Faculty Research Performance Evaluation And The Balanced Scorecard In AU Strategic Planning: A Collaborative Model
}

Fathi Ellington, (E-mail: fathie@ athabascau.ca), Athabasca University David Annand, (E-mail: davida@athabascau.ca), Athabasca University

\begin{abstract}
Quality of research is a core property that enables a university to gain and sustain credibility. The evaluation and measurement of this core property needs to include a wide range of critical factors. This paper suggests the use of the balanced scorecard (BSC) approach as a powerful tool to link faculty research activity to university strategic planning. Though widely embraced by the corporate sector, BSC has not been applied in the higher education sector of the economy, in part because of the lack of quantitative performance measures. This paper presents application of BSC to a Canadian university, including a quantified performance measurement system. The development of the system, its components, the intended outcomes, and the necessary characteristics that should enable BSC to be applied generally to any university's overall strategic plan are described.
\end{abstract}

\subsection{Introduction}

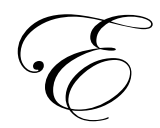

volving societal expectations about the role of higher education require new strategic responses from university executive officers to achieve success in all aspects of the their universities' mandates. This includes the development of processes that align individual faculty members' research objectives with the university's overall research plan, and measure the success of this objective - all in a collegial, democratic spirit that should undergird a well-functioning university.

It is common for universities to insert a goal of research excellence into their mission statement, as this provides explicit support for this important function. Unfortunately, institutional strategic objectives and implementation plans related to research activity are generally vague. Independent thought is encouraged to a greater degree in academe, universities are usually publicly funded and therefore less responsive to market demands and the adoption of "business practices" is often viewed as undemocratic by faculty members. However, without an effective research performance measurement system, universities can experience faculty dissatisfaction, lowered quality and quantity of research activities, and eventually an overall decline in academic credibility.

University executives tend to employ budget-based controls. "Meeting budget" becomes the primary indicator of organizational success. However, there is often regarded as dictatorial by faculty. Further, there is little linkage between the multiple strategic objectives of the university and this type of control system, particularly with regard to research activity. This is unfortunate, because faculty research is a defining characteristic of universities, and is recognized as an important dimension for achieving institutional excellence. A strong and well-designed university research profile contributes to the creation of new knowledge, maintains and strengthens the quality of a university's programs, increases funding from external sources, and enhances the institution's leadership role.

Readers with comments or questions are encouraged to contact the authors via email. 
The balanced scorecard framework (BSC) was developed to translate profit-oriented businesses' missions and strategies into four categories of objectives, and then provide a means to link and evaluate these objectives. The process enables firms to remain focussed, innovative, and successful. The framework is described below. It is suggested that an adapted version of this framework provides a suitable, alternate performance measurement system that can improve success in faculty research activity in a university setting.

\subsection{The Balanced Scorecard}

The balanced scorecard (Kaplan and Norton, 1992) encourages senior managers to understand the determinants of long-term organizational success. Related objectives must flow from these determinants, both financial and non-financial measures must be incorporated into the institution's information systems, and staff must consider the institutional consequences of their decisions and actions. From a strategic perspective, the BSC can be used to:

- $\quad$ Clarify and gain consensus about strategy;

- $\quad$ Communicate strategy throughout the organization;

- $\quad$ Align departmental and personal goals to the strategy;

- $\quad$ Link strategic objectives to long-term targets and annual budgets;

- $\quad$ Identify and align strategic initiatives;

- $\quad$ Perform periodic and systematic strategic reviews; and

- $\quad$ Obtain feedback to learn about and improve strategy. (Kaplan and Norton, 1996)

BSC proposes that significant stakeholders must evaluate their firm's business processes from at least four major perspectives. Adapted to a university research setting, these perspectives can be represented by four questions:

1. What are the financial measures of the university's research activity? The primary purpose of this financial perspective is to examine how a university's researchers might position their research work to attract a predetermined level of research grants, while maintaining academic freedom. To operationalize this, faculty need to set internal and external grant targets, and identify specific initiatives to reach these targets.

2. How does the scientific community view the university's research activities? This scientific perspective measures scholarly acceptance. Faculty members need to target relevant scientific circles to which they can contribute, and specify how their contributions will be measured. Core outcome measures could include publications in refereed journals, conference presentations, papers reviewed, membership on editorial boards, or participation in other pre-specified research activities.

3. What service processes must the university improve and excel at? This internal service perspective is measured primarily by improvements in the support of research within the institution. Since faculty need time and administrative support to conduct research, the means to help researchers carry out all their assigned duties efficiently is needed, as well as ways facilitate individual and group research activities.

4. How can the university continue to learn and innovate? This learning and growth perspective identifies the infrastructure that the organization must build to create long-term growth and improvement in research activities. It can be measured in part by time and funds the organization devotes to faculty training and development, but also by improvements in the processes whereby individual faculty members' are able to effectively communicate what they have learned to others in the organization.

These four perspectives provide the "balance" needed to effectively operationalize, measure, and assess a university's strategic research program. For instance, financial considerations should not primarily drive research agenda. Though BSC recognizes that the organization must limit its spending to budgeted amounts, more importantly it recognizes that success cannot be measured merely by the degree to which this is accomplished. Reducing research expenses by $10 \%$ of budgeted amounts cannot be considered successful if the organizational mission has been severely compromised, and critical constituencies alienated.

Instead, the BSC approach encourages consideration of a wider range of measurements, and from a variety of perspectives. When these measures are democratically determined and flow directly from a university's mission and 
strategic objectives related to research, they can provide substantial focus, motivation, and accountability in research, as well as an effective means to communicate research objectives to stakeholders.

There is no correct set of performance measurements that every university should employ. In general, the more comprehensive yet concise the set of measures, the greater the probability that the BSC will provide an effective monitoring and management tool. Kaplan and Norton (1996) suggest that performance measures should represent a balance in three areas:

1. Between measures that look outward (financial; scientific perspectives), and measures that focus on internal processes (internal service; learning and growth perspectives).

2. Between lagging measures - those that result from past actions - and leading measures - those that inform future performance. Examples of leading indicators are faculty satisfaction and morale, quality of research activities. Lagging indicators would be various accounting based measures such as a budget versus actual measures. Ideally, selected performance measures should include both types, in order to reflect the institutions' various research objectives.

3. Between easily quantified outcome measures and more subjective measures that may drive these outcomes.

However, it is often difficult in practice to rank the relative importance of these performance measures, determine if quantitative or qualitative measures should be used, or use lag or lead measures. Perhaps the most important question for universities, then, is how key performance measures can be linked to university mission. The analytical hierarchy process suggested by Saaty (1996) links qualitative and quantitative measures to strategic objectives within an integrating framework. It allows complex, collective, and subjective judgments to be structured and analyzed using a rigorous, step-by-step mathematical approach. This approach is particularly appropriate in a university setting, where faculty make decisions collegially and democratically through a process of discussion and consensus. Adapted to research activity, the process involves the following steps:

Step 1 - Construct a model linking the organization's mission to the sub-unit's objectives: The process begins with the construction of a model that links the organization's mission to four categories of strategic research objectives described above. To do this, the model must have an explicit, agreed-upon goal. The model then links the goal (fulfillment of mission), the alternatives (the objectives of the organization or relevant sub-unit) and the criteria use to measure the achievement of theses objectives (BSC measures).

Step 2 - Invite faculty and the appropriate executive officer to jointly discuss and determine the "weights" of each strategic objective. The next step involves the specification of the relative importance of each strategic objective. At this point, management and faculty need to jointly agree on these, as both institutional and faculty perspectives must be represented. This ensures that the underlying, subjective perceptions are accommodated about what degree attainment of a particular strategic objective constitutes attainment of the research goal.

Step 3 - Invite faculty to jointly agree on the type and weight of performance measures for each objectives. After determining the importance of the various strategic objectives, faculty agree on performance measures relevant to each of the four strategic research objectives, and assess each measure's relative importance to the achievement of the related objective. At this point, faculty alone define how attainment of a particular objective will be defined and measured. The baseline or targeted values computed in this step provide an indexed score against which the actual results for each academic year are measured.

Step 4 - Use these strategic objectives and performance measures to construct an index to monitor performance: The relative weights of each performance measure are multiplied by the relative weight assigned to each strategic objective. The resulting "scorecard" indicates the importance of various research activities to the group, guides activity choices of individual faculty members, and allows overall group activity targets to be specified and compared to actual activity levels at a later date.

Step 5 - Faculty set individual research goals in the context of the pre-specified performance measures. An individual faculty member does not need to establish a goal for every measure. These goals need to be reviewed with the supervisor to ensure that the proposed workload is reasonable and achievable. The measures are quantified. Estimated days to accomplish each measure is calculated, ensuring that the overall amount of days devoted to scholarly activity (60 days, also pre-determined by group) is met but not exceeded. Related tasks necessary for the performance of each measure need to be specified (refer to 'Appendix A' for an example). 
Step 6 - Actual achievement of individual, pre-specified measures is reported at the end of the academic year. Projected individual research levels for various performance measures are aggregated and compared to the target activity level. Variances from planned activity levels are calculated, and overall faculty performance is evaluated.

A case study described below illustrates how these BSC concepts have recently been applied to a research program in one faculty sub-unit of a Canadian university.

\subsection{Case Study: Research activity in the School of Business at Athabasca University ${ }^{1}$}

Athabasca University is located in Alberta, Canada. Its mission is to reduce barriers that traditionally restrict access to university-level education for all adults. Its primary educational market is Canada and the United States. To accomplish its mission, the University has adopted open access policies - for instance, offering distance education courses, admitting any adult regardless of prior education, arranging comprehensive transfer credit arrangements with other educational institutions, and pioneering work in prior learning assessment for university credit.

Students can start courses at any time during the year and can complete these at their own pace within a six month contract period. Individualized academic support is provided to students in the form of telephone and e-mail support from full-time faculty or part-time academic experts. Most of the growth in undergraduate course enrollments has occurred in independent study courses that still rely heavily on paper-based instructional material and an industrialised delivery model. The University's course development and delivery processes exhibit many of the industrialized production characteristics described by Peters (1983). The institution continues to mass-produce standardized, carefully-structured instructional media, and to differentiate course development, production, and instructional labour processes in order for instructors' knowledge and skills to be transmitted in a cost-effective manner to a large number of students. Duties that would normally be performed by one classroom instructor are instead distributed among several members or units within the organization, and technology supplants many of the instructional techniques of face-toface instruction.

Despite this emphasis on teaching at a distance and though it is recognized as an international leader in individualized distance education methods and technologies, the University is dedicated to research and scholarship in many disciplines. Research activity by faculty is within the norm of other universities. As in any university, there is a healthy dialogue among researchers who may examine the same broad issues from within different research paradigms.

Like the three other Alberta universities, Athabasca University's level of government funding is based on how well the University achieves certain key performance indicators like number of graduates and percentage growth. The University has done well under this funding arrangement - undergraduate enrollments have grown more than $25 \%$ compounded annually over the last four years, and graduate programs even more - but state funding is not tied proportionately to growth in enrolment levels. As enrolments increase, the University receives a smaller percentage of its total revenue from government and becomes more reliant on tuition fees. Operating grants have shrunk from about $78 \%$ of total revenues to under $40 \%$ in just seven years. As a result, there is increasing incentive to consider measures that will improve all aspects of the University's performance, including research activity.

Following extensive discussions, and consultations with internal and external stakeholders over a one-year period, the University recently completed its Strategic University Plan (SUP) for the 2002-2005 period. The University's mission statement in this document states,

"Athabasca University, Canada's Open University is dedicated to the removal of barriers that restrict access to, and success in, university-level studies and to increasing equality of educational opportunity for adult learners worldwide. We are committed to excellence in teaching, research and scholarship, and to being of service to the general public." (p. 5)

\footnotetext{
${ }^{1}$ Visit < http://www.athabascau.ca> to know more about Athabasca University and its Strategic Plan.
} 
A core value of the SUP relates to the "scholarship of discovery". The plan commits the University to the pursuit of research excellence, to developing an annual, three-year, rolling comprehensive research plan, and to increasing faculty research output in terms of publications, contracts, grants, and awards.

Faculty in the University's School of Business undertook to operationalize the research mission and broadly stated research goals contained in the SUP. The School offers undergraduate business courses. These courses account for about 13,000 annual registrations, or over 1/3 of the University's total undergraduate registrations. At present, there are about 25 full-time faculty members in the School, over 70 part-time markers and academic experts, and about 20 full-time professional and support staff.

In April 2002, the Vice President, Academic (VPA) and the School's full-time faculty members conducted a one-day research workshop. The aim of the retreat was to use the Balanced Scorecard approach to collegially develop an initial one-year research plan that would enable faculty research activity to be measured and evaluated using agreedupon measures. The workshop activities followed the steps outlined above.

\section{Step 1 - Construct a model linking the organization's mission to the sub-unit's objectives:}

Following an explanation of the BSC framework, faculty and the VPA jointly discussed the School's appropriate research goal in the context of the University's stated mission statement. The agreed upon goal was to "increase the level and quality of research activity in the School of Business." Four key objectives and associated enabling statements were developed, corresponding to the four perspectives noted above. These are illustrated in the BSC framework diagram below:

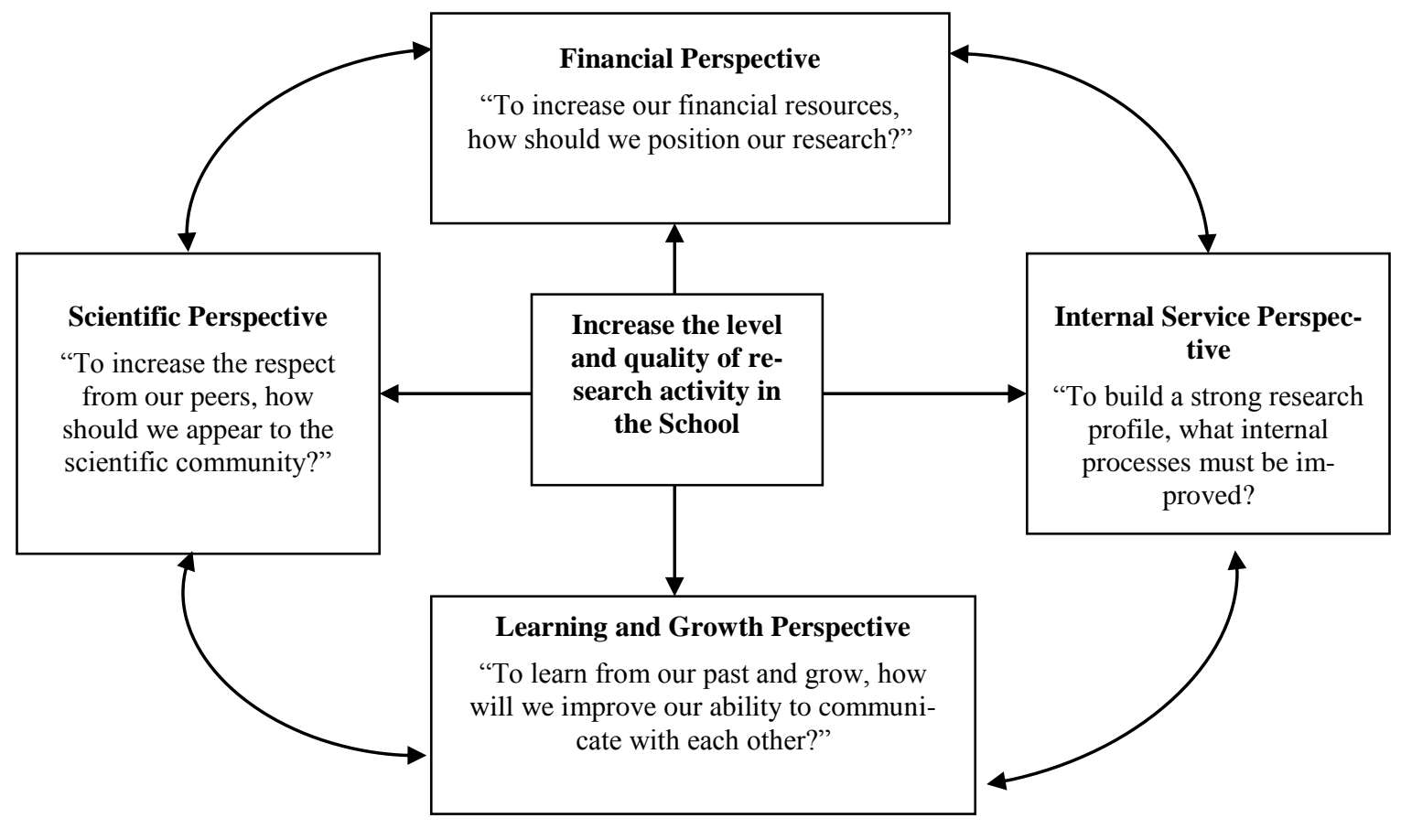

Exhibit 1: BSC in a University Research Environment (Adapted from R. S. Kaplan and D. P. Norton, 1996, The Balanced Scorecard: Translating Strategy into Action, Harvard Business School Press, p. 9)

The four objectives are essential to the development of the balanced scorecard. However, relative weights of each objective need to be determined. 
Step 2 - Invite faculty and the appropriate executive officer to jointly discuss and determine the "weights" of each strategic objective

This step ranks the four strategic objectives in relative importance to the overall goal of increasing the level and quality of faculty research activity. After discussion and consensus-making among the group, the strategic objectives were weighted in terms of relative importance as follows:

- $\quad$ Increase financial resources $10 \%$

- $\quad$ Scientific recognition $70 \%$

- $\quad$ Key internal process improvement $\quad 10 \%$

- $\quad$ Faculty development and retention $10 \%$

Step 3 - Invite faculty to jointly agree on the type and weight of performance measures for each objectives.

Faculty alone were then asked to determine the performance measures within each of the four objectives. Following another round of suggestions and consensus-making, these measures were defined as:

1. Increase financial resources for research by

a. obtaining internal grants.

b. obtaining external grants.

2. Enhance recognition in scientific community by

a. submitting publications to refereed journals.

b. presenting at conferences.

c. publishing papers in discipline-specific refereed journals, and textbooks.

d. reviewing papers for discipline-specific journals.

e. presenting at other universities.

f. inviting outside faculty to present at Athabasca University.

3. Improve key internal processes by

a. arranging/attending grant application workshops.

b. improving grant applications.

c. taking research days (defined by consensus as a total of 200 working days/year $\mathrm{x} 30 \%=60$ days).

d. $\quad$ editing and revising working papers.

4. Enhance faculty development and retention by

a. increasing training and development in discipline-specific methods.

b. $\quad$ increasing training and development in multi-disciplinary research methods.

c. building research teams and networks.

d. promoting SB faculty research.

Step 4 - Use these strategic objectives and performance measures to construct an index to monitor performance: In the workshop, faculty then assigned a target level of importance to each measure (total $=100 \%$ within each category).

When multiplied by the relative weight assigned to each strategic research objective, the results serve as indices to track future performance. Exhibit 2 illustrates this process.

Step 5 - Faculty set individual research goals in the context of the pre-specified performance measures. Once faculty agree that these measures and weights accurately reflect their collective opinion, each faculty member fills out a worksheet similar to that shown in appendix A. An example of a completed individual faculty balanced scorecard is shown as well in the same appendix.

Step 6 - Actual achievement of individual, pre-specified measures is aggregated and reported at the end of the academic year. The aggregated target activity levels computed in step 5 provide an index against which the actual results for the academic year are measured. This enables the organization's progress in carrying out its research objectives to 
be tracked. Exhibit 3 shows the aggregated, projected results, as well as the actual (assumed) aggregated results of the School of Business faculty members after one year.

Exhibit 2 - AU Research Performance Measurement Index

\begin{tabular}{|l|c|c|}
\hline Performance Measure & Target & Weight \\
\hline Financial Perspective & & $\mathbf{1 0 . 0 \%}$ \\
\hline a. Internal grants & $20 \%$ & $2.0 \%$ \\
\hline b. External grants & $80 \%$ & $\mathbf{7 0 . 0 \%}$ \\
\hline Scientific Perspective & & $7.0 \%$ \\
\hline a. Refereed paper production & $10 \%$ & $7.0 \%$ \\
\hline b. Conference presentations & $10 \%$ & $35.0 \%$ \\
\hline c. Publications in refereed journals & $50 \%$ & $10.5 \%$ \\
\hline d. Reviewing papers in journals & $15 \%$ & $7.0 \%$ \\
\hline e. Paper presentation at other universities & $10 \%$ & $3.5 \%$ \\
\hline f. External invitation for presentation at AU & $5 \%$ & $\mathbf{1 0 . 0 \%}$ \\
\hline Internal Process Perspective & & $5.0 \%$ \\
\hline a. Grant application workshops & $50 \%$ & $1.0 \%$ \\
\hline b. Improving grant applications & $10 \%$ & $3.0 \%$ \\
\hline c. Taking allotted research time & $30 \%$ & $1.0 \%$ \\
\hline d. Editing and revising working papers & $10 \%$ & $\mathbf{1 0 . 0 \%}$ \\
\hline Learning and Growth Perspective & & $2.0 \%$ \\
\hline a. Learning discipline-specific research methods & & \\
\hline b. Learning multi-disciplinary research methods & & $1.0 \%$ \\
\hline c. Research team building & $20.0 \%$ & $1.0 \%$ \\
\hline d. Rewards and recognition & $10.0 \%$ & $6.0 \%$ \\
\hline Baseline Performance Index & $10.0 \%$ & $\underline{\mathbf{1 0 0} \%}$ \\
\hline
\end{tabular}

"\% of target" for each measure is calculated by dividing the academic year actual results by the target amount times 100. For example, the actual internal grants received by all School of Business faculty was $\$ 10,000$, or $59 \%$ of the target amount of $\$ 17,000$. This amount multiplied by the projected performance index of $2 \%$ leads to an actual performance index of $1.2 \%$ for this measure $(59 \% \times 2 \%)$.

Year 1 overall performance index was $65.0 \%$, suggesting that School of Business faculty fell short of its target. It only met two of its performance measure targets (conference presentations and papers reviewed) and generally fell far short in the rest. The most significant negative effects are the failure to obtain the expected level of external grants $(-5.5 \%)$, to publish in refereed journals $(-11.5 \%)$, and take time to build recognition for research accomplishments $(-6.0 \%)$. However, the most significant of these indices may be the failure of faculty to take allotted research time. The faculty took a total of 80 person days less research time than anticipated, perhaps because of teaching and other duties. Though the effect of this factor on the actual overall performance index is minimal (-.9\%), it may have caused the underperformance observed in a number of other categories. This result could also support the common faculty argument that research time is impinged by other duties. In the following year, this measure should perhaps be assigned more relative weight. With several years' experience, this measure could turn out to be the bellwether index that significantly drives all other faculty research performance.

In the interim, the balanced scorecard provides a detailed analysis of how well performance measures were or were not met, and how these contributed to the overall research activity of the faculty. The School of Business plans to implement a webpage to capture and compile actual research results to make this process transparent and efficient. 


\begin{tabular}{|c|c|c|c|c|c|c|}
\hline Performance Measure & $\begin{array}{c}\text { Year } 1 \text { Actual } \\
\text { (Assumed) }\end{array}$ & Year 1 Target & $\begin{array}{c}\% \text { of } \\
\text { Target }\end{array}$ & $\begin{array}{c}\text { Projected } \\
\text { Performance } \\
\text { Index }\end{array}$ & $\begin{array}{c}\text { Actual } \\
\text { Performance } \\
\text { Index }\end{array}$ & $\begin{array}{c}\text { Differ- } \\
\text { ence }\end{array}$ \\
\hline Financial Perspective & & & & $10.0 \%$ & $3.7 \%$ & $-6.3 \%$ \\
\hline a. Internal grants & $\$ 10,000$ & $\$ 17,000$ & $59 \%$ & $2.0 \%$ & $1.2 \%$ & $-.8 \%$ \\
\hline b. External grants & $\$ 20,000$ & $\$ 65,000$ & $31 \%$ & $8.0 \%$ & $2.5 \%$ & $-5.5 \%$ \\
\hline Scientific Perspective & & & & 70.0\% & $55.1 \%$ & $-14.9 \%$ \\
\hline a. Refereed paper production & 7 articles & 8 articles & $88 \%$ & $7.0 \%$ & $6.2 \%$ & $-.8 \%$ \\
\hline b. Conference presentations & 12 presentations & 11 present. & $109 \%$ & $7.0 \%$ & $7.6 \%$ & $+.6 \%$ \\
\hline c. Publications in refereed journals & 8 publications & 12 publications & $67 \%$ & $35.0 \%$ & $23.5 \%$ & $-11.5 \%$ \\
\hline d. Reviewing papers in journals & 5 articles & 4 articles & $125 \%$ & $10.5 \%$ & $13.1 \%$ & $+2.6 \%$ \\
\hline e. Paper presentation at other universities & 2 presentations & 4 presentations & $50 \%$ & $7.0 \%$ & $3.5 \%$ & $-3.5 \%$ \\
\hline f. External invitation for presentation at AU & 1 presentation & 3 presentations & $33 \%$ & $3.5 \%$ & $1.2 \%$ & $-2.3 \%$ \\
\hline Internal Process Perspective & & & & $\mathbf{1 0 . 0 \%}$ & $5.5 \%$ & $-4.5 \%$ \\
\hline a. Grant application workshops & 3 workshops & 7 workshops & $43 \%$ & $5.0 \%$ & $2.2 \%$ & $-2.8 \%$ \\
\hline b. Improving grant applications & 3 applications & 6 applications & $50 \%$ & $1.0 \%$ & $.5 \%$ & $-.5 \%$ \\
\hline c. Taking allotted research time & 180 person days & 260 person days & $69 \%$ & $3.0 \%$ & $2.1 \%$ & $-.9 \%$ \\
\hline d. Editing and revising working papers & 8 papers & 11 papers & $73 \%$ & $1.0 \%$ & $.7 \%$ & $-.3 \%$ \\
\hline Learning and Growth Perspective & & & & $10.0 \%$ & $.7 \%$ & $-9.3 \%$ \\
\hline a. Learning discipline-specific research methods & 5 days & 25 person days & $20 \%$ & $2.0 \%$ & $.4 \%$ & $-1.6 \%$ \\
\hline b. Learning multi-disciplinary research methods & 0 days & 5 person days & $0 \%$ & $1.0 \%$ & $0 \%$ & $-1.0 \%$ \\
\hline c. Research team building & 1 day & 4 person days & $25 \%$ & $1.0 \%$ & $.3 \%$ & $-.7 \%$ \\
\hline d. Rewards and recognition & 0 days & 2 person days & $0 \%$ & $6.0 \%$ & $0 \%$ & $-6.0 \%$ \\
\hline Baseline Performance Index & & & & $100 \%$ & $65.0 \%$ & $-35.0 \%$ \\
\hline
\end{tabular}

Exhibit 3 - School of Business Research Performance Measurement Index 


\subsection{Conclusion}

The balanced scorecard can play a central role in contributing to the accomplishment of an organization's mission, by linking this to strategic objectives and related performance measures in a coherent framework. It can be applied to a variety of environments, including a university's strategic research goals, by using the described hierarchy process. A case study described the experiences to date of using the BSC approach in the School of Business faculty at Athabasca University. Analysis of this case study suggests that the BSC framework can be adapted to assess and monitor research performance in a variety of university settings, and to develop an overall performance index specifically geared to the strategic plan of any research institution. The organization is able to assess research performance, determine weaknesses, and institute remedial action. In a sense, the performance index becomes the "bottom line' in measuring organization's performance in achieving its overall goal.

\section{References}

1. Bryson, John M. (1995). Strategic Planning for Public and Non-profit Organizations, San Francisco: JosseyBass.

2. Kaplan, R.S. and Norton, D.P. (1992). The Balanced Scorecard: Measures that drive performance, Harvard Business Review 70. 71-79.

3. Kaplan, R.S. and Norton, D.P. (1996). The Balanced Scorecard: Translating Strategy into Action. Boston, MA: Harvard Business School Press.

4. Peters, O. (1983). Distance teaching and industrial production: A comparative interpretation in outline. In D. Seward, D. Keegan, and B. Holmberg (Eds.), Distance Education: International Perspectives (pp. 95-113). New York: Routledge.

5. Saaty, T. L. (1996). The Analytic Hierarchy Process___Pittsburgh, PA: RWS Publications.

\begin{tabular}{|c|c|c|c|}
\hline \multicolumn{4}{|c|}{$\begin{array}{c}\text { Appendix A } \\
\text { Completed Individual Faculty Balanced Scorecard }\end{array}$} \\
\hline sic Objective / Measure & Target & Initiatives & Implications \\
\hline \multicolumn{4}{|l|}{ ial Perspective } \\
\hline ual internal grant & $\$ 2,000$ & $\begin{array}{l}\text { - Apply to the ARF and/or } \\
\text { - Apply to the MCRF [deadline Feb. 28] } \\
\text { - Or other research internal funds }\end{array}$ & $\begin{array}{l}-3 \text { days to prepare application } \\
\text { (Feb. } 10-13)\end{array}$ \\
\hline ual external grant & $\$ 5,000$ & $\begin{array}{l}\text { - Apply to SSHRC [deadline October 1] } \\
\text { - Apply to CANARIE [deadline May 15] } \\
\text { - Others }\end{array}$ & $\begin{array}{l}-6 \text { days from Sept. } 1-7 \\
-6 \text { days from April } 20-25\end{array}$ \\
\hline \multicolumn{4}{|l|}{ fic Perspective } \\
\hline reed paper production & 2 & $\begin{array}{l}\text { - Identify research questions } \\
\text { - Hire research assistants } \\
\text { - Attend relevant research workshops } \\
\text { - Readings literature } \\
\text { - Writing (authoring/ co-authoring) papers }\end{array}$ & $\begin{array}{l}\text { - } 10 \text { days, to be planned accor } \\
\text { grant applications outcome sc }\end{array}$ \\
\hline ference presentations & 1 & $\begin{array}{l}\text { - Identify target conferences } \\
\text { - Apply before the deadline and make early bird registration to save } \\
\text { money on budget. } \\
\text { - Seek other roles: chair, discussant... } \\
\text { - Attend the conference }\end{array}$ & $\begin{array}{l}\text { - } 4 \text { days to attend the two con } \\
\text { ences }\end{array}$ \\
\hline lications & 2 & $\begin{array}{l}\text { - Identify target journals } \\
\text { - Approach their circles and be involved } \\
\text { - Submit papers for publications } \\
\text { - Make requested revisions till publication }\end{array}$ & $\begin{array}{l}\text { - } 10 \text { days for submitting and } r \\
\text { papers for publication. }\end{array}$ \\
\hline nal refereeing & 1 & - Identify target journals & -5 days for refereeing in Jour \\
\hline
\end{tabular}




\begin{tabular}{|c|c|c|c|}
\hline & & $\begin{array}{l}\text { - Approach their circles and propose your service } \\
\text { - Participate and make a notable contribution }\end{array}$ & \\
\hline presentation at other univer- & 1 & $\begin{array}{l}\text { - Submit a request for a presentation (i.e. L-\&-L) } \\
\text { - Invite people to attend } \\
\text { - Ask for feedback }\end{array}$ & $\begin{array}{l}-2 \text { days for preparing the pres } \\
\text { tion and presenting the paper }\end{array}$ \\
\hline nal invitation for presentation & 1 & $\begin{array}{l}\text { - Approach and propose an external faculty to come to AU for a presen- } \\
\text { tation } \\
\text { - Invite people to attend } \\
\text { - Ask for feedback and send them to invitee }\end{array}$ & $\begin{array}{l}\text { - } 1 \text { days to accompany the inv } \\
\text { and present him to other AU f }\end{array}$ \\
\hline \multicolumn{4}{|l|}{ al Process Perspective } \\
\hline nt applications workshops & 1 & $\begin{array}{l}\text { - Identify your need } \\
\text { - Specify the appropriate date for the workshop } \\
\text { - Attend the workshop }\end{array}$ & - 1 day to attend the workshop \\
\hline t applications editing and re- & 2 & $\begin{array}{l}\text { - Book time from editors/reviewers } \\
\text { - Get applications ready way before deadlines }\end{array}$ & - 2 days to make req. changes \\
\hline allotted research days & 60days & $\begin{array}{l}\text { - Total days needed for research and identified in all perspectives of the } \\
\text { BSC } \\
\text { - Plan your research leave for the next year }\end{array}$ & $\begin{array}{l}\text { - Arrange coverage } \\
\text { - Means that you are NOT av: }\end{array}$ \\
\hline orking paper editing and re- & 2 & $\begin{array}{l}\text { - Book time from editors/reviewers } \\
\text { - Get working papers ready way before deadlines for submission }\end{array}$ & - 2 days to make req. changes \\
\hline \multicolumn{4}{|l|}{ ng and Growth Perspective } \\
\hline $\begin{array}{l}\text { arning discipline-specific re- } \\
\text { methods }\end{array}$ & 2 days & $\begin{array}{l}\text { - Identify your need (i.e. learn software, application, new technology, } \\
\text { statistics tool...) } \\
\text { - Send information and locate where this can be offered (inter- } \\
\text { nally/externally) } \\
\text { - Attend the training and development sessions } \\
\text { - Make information available to your colleagues }\end{array}$ & $\begin{array}{l}\text { - } 2 \text { days needed to attend train } \\
\text { and development sessions and } \\
\text { feedback to my colleagues }\end{array}$ \\
\hline rning multi-discipline research & 3 days & $\begin{array}{l}\text { - Specify the other discipline and the researcher(s) to work with } \\
\text { - Do relevant readings } \\
\text { - Initiate a research project with her/him/them }\end{array}$ & $\begin{array}{l}\text { - } 3 \text { days for the readings, discl } \\
\text { and learning process. }\end{array}$ \\
\hline earch team building & 2 days & $\begin{array}{l}\text { - Identify a research team circle(s) } \\
\text { - Discuss research issues and opportunities } \\
\text { - Share information and send alerts } \\
\text { - Motivate, participate and share responsibilities } \\
\text { - Use the team synergy as a powerful tool for networking and publication }\end{array}$ & - 2 days needed \\
\hline ards and Recognition & 1 day & $\begin{array}{l}\text { - Target at least one award (i.e. best paper award, notable contribution } \\
\text { award, fellowship... } \\
\text { - Differentiate your work by being innovative and seeking high quality } \\
\text { - Involve your research team circle to reach this target }\end{array}$ & - 1 day needed \\
\hline
\end{tabular}


